\title{
Kitap Değerlendirmesi: Hakan Ertin, Merve Özaykal (Ed.). Hayat Ne Zaman Başlar, Ne Zaman Biter? (İstanbul, isAR Yayınları, 2019). ISBN: 978-605-9276-16-0
}

\section{Mine Doğan* 우}

Günümüzde teknolojinin akıl almaz bir şekilde ilerlemesi, içinde bulunduğumuz durumun eskiye oranla farklılaşmasına ve girift bir hal almasına sebep olmuştur. Şüphesiz şahit olduğumuz bu gelişmeden tıp ilmi de nasibini almış ve daha hayatın başlangıcı diyebileceğimiz bir aşamada anne karnındaki ceninin cinsiyetine müdahale edilme imkanı doğmuş, adeta vücudun merkezi konumunda olan beyin sapının tahrip olmasına binaen yaşanan beyin ölümü durumunda respiratörün (sun'i solunum cihazı) kullanılmasıyla tıbbi uygulamalar yepyeni bir veçheye bürünmüştür. İnsanın hayata başlangıcı ve veda etmesi aşamasındaki bu icraatlar geçmişte insan bedeni üzerine belirlenen çizgileri muğlaklaştırmış ve çağdaş tıbbi uygulamalar bütüncül bir şekilde insanın sınırlarını yeniden ele almayı gerekli kılmıştır. Bu durum tıp, hukuk, etik, psikoloji, sosyoloji ve din alanında yeni çalışmalar yapılarak durumun değerlendirilmesini elzem kılmıştır. İşte tam da bu aşamada elimizde bulunan değerlendirmesini yaptığımız bu kitap, tıp camiasındaki modern uygulamaları daha çok dini boyutu merkeze alarak farklı disiplinlere göre masaya yatırmaktadır.

$\mathrm{Bu}$ eser dokuz yıldır tıp ve sağlık alanındaki uygulamaların İslami yönden değerlendirilmesine eğilen İstanbul Araştırma ve Eğitim Vakfı Tıp ve Ahlak Çalışma Grubu (ISAR, TAÇG) tarafından düzenlenen iki ayrı çalıştayda farklı alanlardan katılan akademisyenlerin sunduğu tebliğlerin kitaplaştırılmış halidir. İstanbul Tıp Fakültesi Tıp Tarihi ve Etik Anabilim Dalı'nda öğretim üyesi olup yakın zamanda kaybettiğimiz merhum Prof. Dr. Hakan Ertin ve İstanbul Üniversitesi İlahiyat Fakültesi İslam Hukuku Anabilim Dalı'nda biyo-fıkıh çalışmalarını yürüten Dr. Öğr. Üyesi Merve Özaykal'ın editörlüğünde

\footnotetext{
* Sorumlu Yazar: Mine Doğan, İstanbul Üniversitesi, Sosyal Bilimler Enstitüsü, İslam Hukuku Ana Bilim Dalı, İstanbul, Türkiye. E-posta: m.dogan4501@gmail.com ORCID: 0000-0001-9638-5774
} 
meydana getirilen bu kitap, biyo-medikal fikıh alanındaki çalışmaların azlığ dikkate alınırsa alandaki boşluğu doldurma adına çok değerli katkılar sunmaktadır. Kitap genel olarak iki bölümden oluşmaktadır ve ilk bölümü oluşturan çalıştayın başlığ 1 "Yaşamın Başlangıcına Dair Fıkhi ve Tıbbi Meseleler" olup bu çalıştay 30 Nisan 2011 y1lında gerçekleştirilmiştir. 9 Haziran 2012 tarihinde gerçekleşen çalıştayın başlığı ise "Hayatın Sonuna Dair Fıkhi ve Tıbbi Meseleler" dir. Kitaptan anladığımıza göre eserin yazılış amacı, başta kadim ilim birikimimize dayanarak ama modern tıbbın ispat ettiği verileri de görmezden gelmeyerek yaşamın başlangıcı ve sona ermesi hakkında tıp etiği ve İslami değerler bazında fikirler vermektir. $\mathrm{Bu}$ amacın gerçekleştirilmesi için çeşitli alanlardan uzman kişilerin katılımıyla zuhur eden adeta bilim şöleni diyebileceğimiz bir ortam tescil edilerek iki kapak arasına konmuştur.

Kitaba alınan bildirilerin neleri ihtiva ettiğinden kısaca bahsederek kitapta verilen mesaj hakkında genel bir tasavvur oluşturmak yerinde olacaktır. M. Ertan Kervancıŏglu'nun kaleme aldığ "Yaşama Başlangıcın Kilometre Taşları" başlığ ile başlayan ilk bölümde tıbbi bir perspektifle hamileliğin başlangıcı olan döllenmenin oluşumu ve embriyonun doğuma kadar geçirdiği evreler biyolojik olarak ele alınmıştır. Burada ilk bildiri olarak yaşamın başlangıcının tıp ilminin verilerine göre ele alınmasını konu alan bir sunumun tercihi, bu meseleyi dini ve etik boyutlarıyla ele almadan önce zihinleri konuya hazır hale getirmiştir. Müellifi Şahin Aksoy olan "İslami Metinler Doğmamış Çocuğun Ahlaki Durumu Problemini Çözmeye Yardımcı Olabilir mi?” adlı makalede kutsal metinlere göre Yahudilik ve Hıristiyanlık dinlerinde bir canlının hangi aşamada insan olma vasfi kazandığ 1 incelenerek konunun daha kapsamlı bir şekilde anlaşılması sağlanmıştır. Son kertede sıra İslam dinine gelince Kur'ân-1 Kerîm'de insanın yaratılış evrelerinden bahseden ayetlerde geçen nutfe, alaka, mudğa vb. kelimeler tıbbi veriler ışığında tahlil edilmiş ve bu konuda serdedilen nebevi hadislere de itibar edilerek İslam dininde canlının döllenmeden 40 gün sonra ruh üflenerek birey olma kimliği kazandığı vurgulanmıştır. Bu tebliğde en çok dikkati çeken husus nasslarda zikredilen merhalelerin adlarının modern tıbbi terminolojideki terimlerle örtüşerek anlatılmasıdır. Bir diğer tebliğde Ali İhsan Pala "İslam Hukuku Açısından Cenin Hakları” başlığı altında İslam hukuku açısından ceninin anne karnında kazandığı miras, vakıf, vasiyet, yaşam hakkı vb. hakları müstakil başlıklar altında incelemiş ve yaşam hakkının uzantısı olarak kürtaj konusunu da ihmal etmemiştir. Bu tebliğde yazarın kürtaj konusunu yaşam hakkıyla irtibatlandırarak ele alması konunun daha somut bir şekilde anlaşılmasına yardımcı olmuştur. Zikredilmeye değer diğer bir bildiri ise Mürteza Bedir ve Halil Kılıç'ın birlikte kaleme aldığ 1 "İnsan Hayatı Ne Zaman Başlar? Ruh-Üfleme Kavramına İlişkin Bir İnceleme” adlı makaledir. Makalede İslam hukukunun 
tarihsel süreci dikkate alınarak fikhın doğuşu, klasik fikıh çağı ve daha sonrası dönemlerinde fukahanın ceninin düşmesiyle cenaze namazı gerekip gerekmediği, düşüğe sebep olma durumunda ödenecek gurre (cenin diyeti) ve ceninin düşmesiyle kadının iddeti ve nifas süresi gibi konulara dair farklı görüşleri dakik bir şekilde ele alınmıştır. Bu bölümde daha çok ceninin kaybedilmesinden sonraki süreçte gerek ceninin (cenaze namazı, defnedilmesi vb.) gerek akrabalarının (gurre) haklarının ne olacağının çözüme kavuşturulması dikkate şayandır.

Tuğba Duru'nun çalışması olan "Ruh Üflenmesi ile İlgili Hadislerin İslam Hukukunda Ceninin Hayatının Sonlandırılmasına Dair Görüşlere Etkisi” adlı tebliğde cenine ruhun üflenmesi vakti yalnız hadisler bağlamında ele alınmış ve bu konuda gelen iki farklı hadise binaen iki farklı zaman belirtilmiştir. Ancak bu bildiriden önceki bir bildiride de aynı konu Kur'ân-1 Kerîm ayetlerinin yanı sıra nebevi hadisler de baz alınarak işlendiğinden dolayı bu sunumun kitaba alınması biraz tekrar izlenimi uyandırmaktadır ve önceki bildirilerden farklı yeni bilgiler sunmamaktadır. Kitaba alınan bildirilerde ecdadımız olan Osmanlı'nın ceninin düşmesi sonucunda kişilere uyguladığı müeyyideler ihmal edilmemiş ve Merve Özaykal'ın kaleme aldığ 1 "Osmanlı Fetvalarında Cenin Düşürmenin Cezai Sonuçları" adlı makaleyle dönemin şeyhülislamlarının önüne getirilen farklı düşük senaryolarına göre verdiği müteaddit fetvalar ortaya konmuştur. Bu sunumun kitaba alınması konuya Osmanlı Dönemi perspektifinden bakmayı sağladığı için konunun daha geniş bir şekilde tasavvur edilmesini sağlamıştır ve çalışmaya farklı bir ambiyans katmıştır.

Kitapta hayatın sonuna dair meselelerin ele alındığg ikinci bölüme Lütfü Hanoğlu'na ait olan "Nörolojik Açıdan Hayatın Sonu: Ölüm" adlı makale ile başlanmıştır. Yoğun bir şekilde tıp ilminin verilerini barındıran bu kısımda tıbbi açıdan farklı ölüm tanımlarına yer verilmiş ve özellikle günümüzde pek çok insanın zihninde sınırları beliremeyen "bitkisel yaşam", "koma", "beyin ölümü" evreleri açıklığa kavuşturulmuştur. Özellikle beyin ölümüne odaklanılarak bu kavrama tarihsel bir yolculuk yapılmıştır. Ayrıca nörolojik açıdan beyin ölümünün betimlenmesinin ardından beyin ölümü tanısının kriterleri tablo formatında açıklanmıştır. Beyin ölümünün diğer bilinç kapalılık durumlarından farkının anlaşılabilmesi adına kavramın tıp ilmi açısından ifade ettiği değerin açıklanması sebebiyle bu makalenin kitaba alınması son derece yerinde olmuştur. İkinci sırada yer alan İlhan İlkılıç’ın kaleme aldığı "Beynin Ölümü İnsanın Ölümü Müdür?’ adlı eserde Harvard Tıp Fakültesi'nin literatüre kazandırdığg beyin ölümü tanımına yer verildikten sonra tartışmanın odak noktasını teşkil eden beyin ölümünün gerçek bir ölüm olup olmayışı hususunda yeni bir sınıflandırma teklif edilmiş, böylece bu alanda söz söyleme yetkileri olan kimseler tespit edilmeye çalışılmıştır. 
Aynı zamanda beyin ölümünü gerçek bir ölüm kabul edenler ve etmeyenlerin argümanlarıyla birlikte zikredildiği bu çalışma, esasen bu evrenin gerçek manada ölüm addedilip edilmemesi adına alana yeni bir kategorizasyon sunması bağlamında oldukça özgündür. Yaşamla ölüm arasında verilen mücadelenin son durağı olan yaşam destek ünitelerini konu edinen Ülfet Görgülü’nün "Yaşam Desteğinin Kısıtlanması Ya Da Sonlandırılmasının Fıkhi Açıdan Değerlendirilmesi” adlı eserinde ise terminal dönemde olan bir hastaya ömür uzatıcı yaşam destek tedavilerinin sağlanmasının gerekli olup olmadığı evrensel etik düzleminde tartışılmış ve yaşam destek ünitelerinin kısıtlanması yahut sonlandırılmasının pasif ötanazi kapsamında değerlendirilip değerlendirilmeyeceği delillerle birlikte zikredilmiştir. Bunun yanında yaşam destek ünitelerinin sınırlandırılmasının İslam fikhındaki anlamı beş zaruri değerden biri olan canın korunması ilkesi, tedaviyi reddetmenin dindeki yeri ve ölüm tespitinin kriterleri bağlamında incelenmiştir.

Merve Özdemir Özaykal’ın yazarlığını üstlendiği “İleriye Yönelik Sağlık Talimatları Uygulaması ve İslam Hukuku Açısından Değerlendirilmesi” adlı çalışmada kişilerin henüz sağlıklı iken olası bir hastalık durumunda bedenlerine yapılacak müdahaleleri sınırlandırmak için kaleme aldığ ayrıntılı bir şekilde ele alındıktan sonra bu belgeler vasiyet, vekalet yahut velayet gibi hukuki işlemler altında incelenmiş ve muhtemel sorunlar dile getirilmiştir. Ayrıca uygulamanın ne tür suistimallere yol açabileceği analiz edilmiş ve uygulamaya meşruiyetini kazandıran tıbbi otonomi ilkesinin problemli yanlarına değinilmiştir. Çalışmaya özgünlügünü kazandıran en önemli husus, ileriye dönük sağlık talimatlarının kişilere tanıdığı tedaviyi red hakkının hasta açısından incelendiği gibi doktor açısından da ifade ettiği değerlerin ve ortaya çıkan ikilemlerin irdelenmiş oluşudur.

Son zamanların popüler uygulaması haline gelen ötanazinin fikhi paradigmadan değerlendirildiği Tuba Erkoç Baydar'ın "Fıkhi Açıdan Hayatın Sonuna İlişkin Tıbbi Sorunlar: Ötanazi” adlı makalesinde İslami anlayışta insanın mahiyeti, dünya hayatının niteliği ve dokunulmazlığı vurgulanarak hayatı yaşanmaya değer kılan unsurların neler olduğu sorusuna cevap aranmıştır. Aynı zamanda gerek aktif gerekse pasif ötanazinin İslam hukukunda ifade ettiği yer açıklanmış ve çeşitlerine göre ötanazi faillerine uygulanacak cezai müeyyideler zikredilmiştir. Çağdaş fukahanın ötanazinin meşruiyeti hakkındaki görüşleriyle sona eren çalışma, ötanaziye dair pek çok soru işaretine cevap bulma noktasında son derece mühimdir. Kitabın son makalesi psikolojik bunalımlar sonucu kişinin kasıtlı bir şekilde canına kıymasını ifade eden intiharın ele alındığı M. Salih Eser'in “İslami Açıdan İntihar” adlı eseridir. $\mathrm{Bu}$ çalışmada intiharın İslam itikadı açısından içerisinde barındırdığı problemler ifade edilmiş olup akabinde cana kıymayı yasaklayan Kur'ânî nasslar ve nebevî 
hadisler yorumlanarak intihar eden kimselerin ahirette karşılaşacakları muameleler betimlenmiştir. Bununla da yetinilmeyip canına kıyan kimsenin yıkanması, cenaze namazının k1lınması, mirası, vekaleti gibi dünyevi hukukunu ilgilendiren meseleler de mercek altına alınmıştır.

Son olarak yazarlığını Dr. Masoud Sabri’nin üstlendiği “İslam Fıkhında Beyin Ölümü” adlı makaleyi değerlendireceğiz. Makalede beyin ölümünün gerçek bir ölüm olup olmadığını savunanların altında zikredilen deliller konu ile tam anlamıyla mutabakat sağlayıp tatmin edici boyutta değildir. Yazar kendisinin beyin ölümünü gerçek manada ölüm olarak görmediğini belirtmiş ancak bu görüşünü haklı çıkarmak için zikrettiği delilleri bildirisinin baş taraflarında da zikrettiği için tekrara düşmüş ve konu hakkında bazı iddialı bilgilere dipnot düşmemiştir. Bildiride bizi en çok şaşırtan, yazarın başlangıçta beyin ölümünü hakiki bir ölüm görmediğini belirtmesine rağmen beyin ölümü gerçekleşmiş bir hastanın yaşam destek ünitesini sonlandırmanın caiz olduğu görüşüne gitmesidir. Çünkü beyin ölümü kişinin hayatının sonu kabul edilmediği sürece o kişi yaşıyor demektir ve bu durumda yaşayan birinin yaşam destek ünitesini çekmek onun hayatına müdahale anlamına gelmektedir. Makaledeki bu çelişkili durum üzerinde düşünülmeye değerdir.

Değerlendirmesini yaptığımız kitap derleme türünde bir kitap olduğundan sabit bir konusu bulunmamaktadır. Merkezde ilk etapta hayatın başlangıcı mesabesinde cenin hakkında sunumu yapılan ve farklı bildirilerden müteşekkil olan ve ikinci bölümde ise merkezde hayatın sonu olduğu düşünülen beyin ölümü, yaşam destek üniteleri, ileriye dönük sağlık talimatları, ötanazi ve intihar konuları etrafında çeşitli bildirilerden oluşmaktadır. Dolayısıyla konular arası irtibattan ziyade merkezi kavramların farklı konular bağlamında ele alınması söz konusudur. Ancak editörlerin makaleleri koyuş sırasındaki uyum bağlamın daha canlı kalmasını sağlamıştır. Yalnız kitapta dikkatimizi çeken bir husus modern dönem tartışmalarının önemli bir kısmını oluşturan ceninden ve beyin ölümü gerçekleşen kişiden organ naklinden bahseden bildirilerin yer almamasıdır. Aslında organ nakli bağlamında makalelerin ilgili yerlere konmasının kitaba daha farklı bir çehre kazandırabileceği kanaatindeyiz. Genel olarak bildirilerin dili sade olup lisans seviyesinde gerek İslami ilimler gerek diğer ilimlerde öğrenim gören talebelere ve bu konulara ilgi duyan kimselere hitap eden, anlaşılması kolay olan bir kitaptır. Eseri makale formatında bildiriler oluşturduğu için ağır ifadeler kullanılmamış, belli bir alana dair terimsel ifadeler geçtiğinde manaları da verilerek akıcılık sağlanmıştır.

Tebliğlerde yerine göre klasik kaynaklar yerine göre modern kaynaklar referans alınmıştır. Kitapta dikkatimizi en çok çeken husus her iki bölümün de başlangıcına kitabın genel bir şablon oluşturmayı hedeflediği cenin ve beyin ölümü konularında 
tıbbi verilere dayanan makalelerin konulmasıdır. Nitekim işin gerek dini gerekse etik boyutunu anlayabilmek için tıp ilminin verileriyle insan mahiyetinin aydınlatılması elzemdir. Modern dönemde gelinen noktada ortaya çıkan tıbbi uygulamalar hakkında genel olarak bir şeyler söyleyebilmek ve işin en temelinde insanı daha yakından keşfedip, tıbbi gelişmeleri takip ederek anlamlandırmak için ilgili çalışmanın istifade edilebilecek eserlerden birisi olduğunu düşünüyoruz. Bu eser çok özel konulardan ziyade bütün insanlığı ilgilendiren ve bilinmesi gereken konuları ihtiva ettiği için ve insan hakkında ufkumuzun genişlemesine hizmet ettiği için herkese önerebileceğimiz bir çalışma mesabesindedir. Daha önce de ifade ettiğimiz gibi bu alanda yeterince akademik çalışma yapılmadığından ötürü ihtiyaç duyulan noktalar ele alınarak alana faydalı bir hizmet olmuştur.

Akademik alanda telif edilen eserler arasında tıp fikhı hakkında daha çok palyatif tıp, hasta mahremiyeti, organ nakli, kürtaj konularında müstakil kitaplar olmasına rağmen elimizdeki kitap gibi merkeze alınan kavramı bütüncül bir bakış açısıyla farklı yönlerden inceleyen bir esere rastlamamamız durumu, esere ayrı bir değer katmaktadır. Kitabın baskısı oldukça kaliteli olup sert kapak kullanılmış ve yaprakları gayet dayanıklı hazırlanmıştır. Değerlendirmesini yaptığımız bu ender kitabın tüm okuyuculara farklı bakış açıları kazandıracağını temenni ediyoruz ve alana merakı olan herkese tavsiye ediyoruz. 